\title{
Making Sense of the Indian Arms Dynamic: A Survey of Military Efforts
}

\author{
Deba R. Mohanty*
}

\begin{abstract}
India's military efforts have been primarily driven by national and regional security considerations, although »power ambitions«, »symbolism « and other factors have also played a complementary role from time to time. Having fought four conventional wars and a limited conflict as well as being confronted with terrorism and increasing internal security challenges, India has undertaken a series of initiatives to modernize its armed forces, arsenal, bureaucratic organizational structure and para-military forces in recent times. India's »arms dynamic « would suggest that while acquisition of state-of-the-art weaponry and emphasis on »self-reliance in defence " point toward an increase in its comprehensive national power, the same may also help explain its ambitions to not only take care of its security concerns at a regional level but also help it to play a constructive role possibly at the global level.
\end{abstract}

Keywords: Military modernisation, arms production, arms procurement, national security

\section{Introduction}

$\mathrm{F}$ rom a realist perspective, states as the principal actors in world politics are perpetually confronted with twin problems of varieties of conflicts on the one hand and conflicts of/competition for core national interests on the other. Hence, the central purpose of statecraft is national survival through promotion of national interests in a competitive, if not wholly hostile immediate neighbourhood/regional or global security environment. In order to achieve such objectives, the states must strive for acquisition of "power « and no principle is more important than »self-help « - the ultimate dependence of the state on its own resources to accumulate national power and promote its interests as well as protect itself ${ }^{1}$. Translated otherwise, a state should acquire a reasonable amount of economic and military might in order to ensure its autonomous character in international affairs. As military power is intricately linked to a state's economic, political, military technological and production variables, it becomes important for the national leadership to promote these for national security purposes.

Not surprising then, military efforts pursued by states have been considered an important subject of inquiry by scholars and analysts to understand behaviour of states in international affairs. However, the study is not as easy one assumes it would be for the very simple reason that military matters have long been treated as state subjects, aspects of military efforts quite often carried out under absolute or relative state of secrecy. Thus, quantitative as well as qualitative aspects of military efforts pursued by states often lead to erroneous assumptions about state behaviour. Although a degree of transparency in military efforts by states, especially evident in the West primarily through analyses of indicators like military expenditure, arms production and trade, force structure and investment in military research and development (R\&D), methodological problems still elude scholarship in gauging the absolute

\footnotetext{
* Dieser Aufsatz wurde referiert (peer-review).

Deba R. Mohanty is a Senior Fellow in Security Studies at the Observer Research Foundation, a premier think-tank located in New Delhi. He specializes on arms trade and industry, military modernization, higher defence organization, national security and strategic culture.

1 For a realist perspective on national security, see, Buzan, Barry, People, States, and Fear: The National Security Problem in International Relations (Surrey: Wheatsheaf Books, 1983).
}

and relative power matrices of states elsewhere. Such problems notwithstanding, military efforts by states, especially those which follow transparency, still help to a considerable extent in understanding the absolute aspects of military power.

Weapons have a number of characteristics, which bear significantly on the workings of the military power and security enhancement that a country engages itself with from time to time. Both these priorities, though they are essentially political in nature, stem from the given condition that states in an anarchy will be armed and responsible for their own defence. Consequently, it comes as no surprise that variations in the character of the weapons, and the dynamics of their production and development, not only influence the two priorities, but constitute a major linking factor to the central objectives of national security. Weapons thus possess an independent, or at least a semi-independent, dynamic of their own. This dynamic, in turn, ties itself into the traditional distinction between capabilities, particularly military power, and intentions $^{2}$. The existence of either is therefore sufficient cause for alarm, and since military capability tends to be visible and durable, whereas intentions are intangible and changeable, more attention gets paid to the former than the latter. Thus, the establishment of an indigenous defence industry or vigorous pursuance of arms acquisition through imports can be seen, from a realist perspective, as an indication of a state pursuing power and autonomy in the international arena.

\subsection{The Indian Arms Dynamic}

The »Arms Dynamic « has gained currency in strategic studies literature in recent times. Barry Buzan and Eric Herring define the term arms dynamic as »an entire set of pressures that make actors (usually states) both modernize armed forces and change the quantity and quality of arms they already possess. The term is used not only to refer to a general global process, but also to inquire into the circumstances of particular states or sets of states $\aleph^{3}$. Explained thus, the arms dynamic tries to explore aspects of military efforts by a state in general and its

\footnotetext{
2 For a detailed explanation, see, Barry Buzan and Eric Herring, The Arms Dynamic in World Politics (London: Lynne Rienner Publishers, 1998). 3 Buzan and Herring, Note 2.
} 
accumulation of military hardware in particular to enhance comparable military capability vis-à-vis its adversary. It is in this context that arms acquisition constitutes a major component of the arms dynamic of a state, a study of which enables us to understand or at least give us clues about the motives behind the state's military efforts.

India's comprehensive national power has drawn considerable attention in recent times. It has been witnessing a spectacular economic growth rate, especially after the country adopted a liberal economic policy and opened up to the world in the early 1990s. Its socio-economic indicators are improving ${ }^{4}$. Its military modernization programme has of late caught the attention of many in the region while its strategic ambitions seem to be factored into the security calculus of major powers. All indicators of Indian military efforts have shown increasing trends - military expenditure, military R\&D, military acquisitions - while accompanying reforms initiated in the higher defence management sector do suggest that India's military power trajectory seems to be in an upward swing ${ }^{5}-$ a trend which is likely to grow further in future. This, in turn, will entail significant strategic implications for the region and elsewhere.

If India's strategic aspirations revolve around attainment of a certain degree of strategic autonomy in international affairs, does its arms dynamic play a role in it? If so, up to what extent? What do trends in India's arms acquisition entail? These are some of the key questions that this paper tries to examine. The paper analyses some key trends in India's military modernization efforts - military expenditure, arms acquisition, domestic production - and tries to establish a possible linkage between arms dynamic and military power. The paper, as explained in the concluding section, would argue that while the need for a comprehensive military modernization has become important in present times, thanks primarily to existence of and increase in security concerns - both traditional and nontraditional - at regional level, India's arms dynamic also gives an impression that it is modernizing its armed forces and arsenal to gear up to face bigger challenges at global levels.

\section{Trends in India's Military Expenditure}

Trend analysis in military expenditure is not as simple as it seems for at least two inter-related factors - availability of information emanating from government sources and different methods applied by analysts on the same information that invariably lead to different assessments. Countries like China typify the first problem - absence of credible information on the Chinese military expenditure from government sources leads to contradictory - either alarmist or dismissive - assessments of the Chinese comprehensive military power. Countries like India typify the second problem - even if open information on India's defence expenditure is available through a variety of government sources, different methods applied by

4 Data related to India's national development and economy are published annually in The Economic Survey by the Planning Commission, a statutory body of the Government of India. Details of the Survey can be found in the official website $<$ http//indiabudget.nic.in $>$. Details of India's annual military expenditure can also be found in this Survey.

5 For details, see, The Annual Report: 2006 (New Delhi: Ministry of Defence, Government of India; 2006). analysts lead to different conclusions about India's military spending patterns. For example, India ranks in the top five military spenders in the world in PPP terms, holds the distinction of the world's top arms recipient (again by PPP terms) even overtaking China in recent times, while it ranks as one of the lowest spenders if constant or current rupee is evaluated in the global military expenditure patterns! Consider this: while the global military spending is pegged at US $\$ 1.12$ trillion at current prices in 2005, the Indian military expenditure stood at slightly more than $\$ 21$ billion - accounting for roughly two percent of the total! Unfortunately, while India's often bloated military expenditure trends are highlighted consistently by institutions like the Stockholm International Peace Research Institute (SIPRI), International Institute for Strategic Studies (IISS) or Congressional Research Service (CRS), very little effort has been made by Indians to demystify such assessments ${ }^{6}$.

Do trends in India's military expenditure reflect a correlation to its emerging grand strategic aspirations or do they merely reflect a $»$ ritualistic tendency ${ }^{7}{ }^{7}$, which in turn is shaped by absolute secrecy, institutional rigidity and absence of a holistic approach? Assumptions are not difficult to make, although subjective interpretations may paint different pictures altogether. Indicative statements like »India's maritime interests spanning from the Gulf of Hormuz to the Malacca Straits« or India as a strategic stabilizer at the world stage $\ll^{8}$ denote a certain amount of confidence in India's strategic thinking, while repeated assurances like »additional funds will always be available for national security purposes $\aleph^{9}$ or $»$ India can increase its defence allocations to 3 percent of the GDP « ${ }^{10}$ seem to complement a correlating continuum. Some elements of India's military expenditure reflect this, while others need an autopsy in the larger framework of analysis.

Allocations for national defence for the year 2007-08 have gone up to Rs. 9,60,000 million (around US \$ 21 billion in current prices) - a rise of 11.4 percent from the last year's revised expenditure. Allocations for »Revenue « expenditure account for 56.33 percent while allocations for »Capital« expenditure account for 43.67 percent of the total defence expenditure (TDE). The TDE in turn accounts for 14.08 percent of the central government expenditure (CGE), less than eight percent of the total government expenditure (both central + state governments), and less than 2.1 percent of the GDP ${ }^{11}$.

\footnotetext{
6 Some Indian analysts have argued for the need for corrections in criteria adopted for data related to military efforts. For details, see, Jasjit Singh, »Conventional Arms Transfers: The Search for Representative Data in Jasjit Singh (ed.), Conventional Arms Transfers (New Delhi: Institute for Defence Studies and Analyses; 1995), pp. $34-47$. Also see, G. Balachandran, »International Arms Transfers: A Case Study« in Jasjit Singh (ed.), note 6, pp. 48 - 59.

7 Indian defence budget is treated as a badinage by scholars and analysts as it is not debated adequately either in the Indian Parliament or elsewhere. See, General (retd.) V. P. Malik \& Deba R. Mohanty, »Defence and Planning March Together «, The Indian Express, 19 February 2007

8 References with regard to India's strategic reach and aspirations can be found in primary documents like the Ministry of Defence Annual Reports. For example, see, note 5. Also see, Deba R. Mohanty, »Arming the Arsenal «, The Pioneer (New Delhi), 24 February 2007.

9 Such assurances especially come from the Finance Minister and the Defence Minister of India from time to time. See, General (retd.) V. P. Malik \& Deba R. Mohanty, »Budgeting for Defence«, The Tribune, 16 March 2007.

10 The Indian Prime Minister Dr. Manmohan Singh had told this to the top military commanders at the Annual Commanders Conference in October 2005. Details of the Prime Minister's speech can be found in $<\mathrm{http} / /$ pmindia.nic.in $>$ 11 Details of allocations for national defence for $2007-08$, including sub-allocations can be found in official website $<$ http//indiabudget.nic.in $>$
} 
Table - 1

India's Defence Expenditure: 1980 - 2007

(In Indian Million Rupees at current prices)

Year Net Revenue Expenditure Net Capital Expenditure Net Revenue \& Capital Expenditure

\begin{tabular}{|c|c|c|c|}
\hline 1980-81 & 35400.38 & 3260.39 & 38660.77 \\
\hline 1981-82 & 42670.24 & 4840.56 & 46510.8 \\
\hline $1982-83$ & 48810.73 & 5260.57 & 54080.3 \\
\hline $1983-84$ & 56660.7 & 6420.47 & 63090.17 \\
\hline 1984-85 & 59230.76 & 7360.75 & 66600.51 \\
\hline $1985-86$ & 70200.13 & 9670.36 & 79870.49 \\
\hline 1986-87 & 91780.97 & 12980.49 & 104770.46 \\
\hline $1987-88$ & 88590.86 & 31070.63 & 119670.49 \\
\hline 1988-89 & 95580.09 & 37820.93 & 133410.02 \\
\hline $1989-90$ & 101940.4 & 42210.77 & 144160.17 \\
\hline 1990-91 & 108740.13 & 45520.35 & 154260.48 \\
\hline 1991-92 & 114410.61 & 49050.43 & 163470.04 \\
\hline 1992-93 & 121080.49 & 54730.3 & 175810.79 \\
\hline 1993-94 & 149770.34 & 68670.39 & 218440.73 \\
\hline 1994-95 & 164250.81 & 68190.42 & 232450.23 \\
\hline $1995-96$ & 188410.24 & 80150.05 & 268560.29 \\
\hline 1996-97 & 209960.66 & 85080.42 & 295050.08 \\
\hline $1997-98$ & 261740.48 & 91030.51 & 352770.99 \\
\hline 1998-99 & 298610.64 & 100350.94 & 398970.58 \\
\hline 1999-00 & 352150.79 & 118540.84 & 470700.63 \\
\hline 2000-01 & 372370.99 & 123840.05 & 496220.04 \\
\hline 2001-02 & 380580.82 & 162060.91 & 542650.73 \\
\hline 2002-03 & 407080.98 & 149520.85 & 556610.83 \\
\hline 2003-04 & 432030.19 & 168620.61 & 600650.8 \\
\hline 2004-05 & 438620.13 & 319930.79 & 758550.92 \\
\hline 2005-06 & 482110.11 & 323370.87 & 805480.98 \\
\hline 2006-07 (RE) & 515420 & 344580 & 860000 \\
\hline 2007-08 (BE) & 540780 & 419220 & 960000 \\
\hline
\end{tabular}

Explanations: 1 US \$ = Indian Rs. 43 approximately; RE = Revised Estimates; BE = Budget Estimates

Source: Defence Services Estimates (New Delhi: Department of Defence Finance, Government of India) for years 1980 to 2006. Figures for the years 2006 - 07 (RE) and 2007 - 08 (BE) have been sourced from the official government of India website related to the Union Budget <www.indiabudget.nic.in>

Indicative trends for the past one decade suggest that while an average growth in GDP has been pegged at seven percent, the average ratio of military expenditure to the GDP has been at around 2.2 percent. An average double-digit growth has been witnessed in military expenditure when calculated in current prices; the same growth has been at slightly more than four percent in real term when calculated in constant prices. Inflation adjusted price as well as escalation of costs at the international arms market could put the real term value of military expenditure further down. Such calculations would put the real value of India's military expenditure at a reasonably minimum level, although it has increased nominally in recent times.

Trends in India's defence expenditure suggest a few pointers. First, the ratio of defence expenditure to the GDP has remained stagnant at around 2.2 percent for the past ten years and is not likely to be hiked despite demands coming from high quarters. Second, India's defence expenditure accounts for less than two percent of the global defence expenditure currently estimated to be $\$ 1.12$ trillion (at current prices) and stands nowhere near big spenders like the US, the UK, France, Germany in the West and countries like China elsewhere. Third, there is a definite trend toward decreasing revenue expenditure while the capital expenditure has witnessed a near three time growth within a span of five years (see Table), which otherwise suggest a preference for military hardware modernization efforts. Fourth, real term increase in India's defence expenditure actually shows a dismal record, if inflation related indicators are taken into account. The real term value of the defence expenditure has indeed declined by around ten percent per annum for the past couple of years. Fifth, a large chunk of the funds earmarked for capital expenditure is surrendered year after year. An average of as much as ten per- 
cent of the budgeted amount for capital acquisition, varying between one and two billion US Dollar, remained unspent for the past five years. Even in the current financial year (200607), the unspent amount is to the tune of US S 700 million $^{12}$. And last but not the least, the share of defence R\&D budget, which currently stands at around US $\$ 1.4$ billion (Rs. 58,000 million), accounts for a paltry 6.15 percent of the total defence budget, while it accounts for around one percent of the total global investment in military R\&D.

\section{Trends in India's Weapons Acquisitions}

Trends in India's military modernisation and arms acquisitions for the past two decades, among others, suggest a deviation from conventional logic. Consider this: India's military expenditure witnessed consistent increase during the $1990 \mathrm{~s}$ when it was just the opposite at a global level, thanks primarily to a sharp decrease in procurement demands in the United States, Europe, Russia and elsewhere. This suggests that the effects of the end of the Cold War that had promised a much needed "peace dividend « had actually impinged less on India's security, while domestic politics, regional security considerations and power ambitions have been considered prime reasons for Indian military modernization efforts. With India's changing strategic thinking, reflected in its desire to be a major strategic stabilizer at the world stage, which in turn has been complemented by consistent enhancement of its national power indices including a near double digit growth rate for the past several years, has necessitated possession of weapons systems in its arsenal that would match its national aspirations. Expanded strategic maritime interests spanning from the Gulf of Hormuz to the Malacca Straits, contemplation on beyond-region military operational exigencies - primarily humanitarian interventionist and stabilization efforts, and India's diplomatic efforts to engage all major powers in the unfolding global power scenario suggest that India must take a re-look at ways to enhance elements of its »hard « power - a reasonable blending of both offensive and defensive capabilities - in order to maximize her national interests ${ }^{13}$.

A closer look at India's military hardware requirements in contemporary times and medium-term future says it all. The last decade has seen eventual induction/agreed supply through license production or otherwise of big-ticket purchases like Su-30 MKI multi-role fighters, Hawk jet trainers, Kilo-class submarines, Admiral Gorshkov aircraft carrier and T-90 main battle tanks (MBTs). In the last three years, India has signed major multi-billion dollar deals with countries like France, Israel and Russia. These include a $\$ 3.5$ billion deal for acquisition and eventual construction of six Scorpenes, a couple of which are expected to have air independent propulsion features, $\$ 1.5$ billion deal to acquire one aircraft carrier, 66 Hawks, Tu-142 bombers, and assorted weaponry, among others. The most recent deals that have been signed with Russia include joint development of fifth-generation combat aircraft, lease of Akula class nuclear powered submarines, multi-role

12 For details, see, Note 11

13 Deba R. Mohanty »Arming the Arsenal«, The Pioneer, 24 February 2007. transport aircraft (to eventually replace the fleet of AN-32 planes) and 200 T-90 MBTs. Recently concluded Aero-India show at Bangalore in February 2007 has witnessed hectic activities related to aerospace business, reportedly pegged at over $\$$ six billion. Near future shopping list includes acquisition of 126 multi-role combat aircraft (MRCA), an array of sophisticated weaponry for the Special Forces, half a dozen warships. The MRCA deal alone is reportedly worth $\$$ five to six billion. To such an extent the big-ticket purchases have played a role that in a span of four years, share of capital expenditure in India's total defence expenditure has crossed 40 percent touch $\$$ eight billion - a 300 percent increase since 2002-03. If the capital purchases worth over $\$$ ten billion for the $11^{\text {th }}$ defence plan period (2007 - 2012) and surge in capital expenditure are of any indication, India is likely to become the world's biggest arms market for the next couple of decades ${ }^{14}$.

\section{Table - 2}

\section{Selected Weapons Systems Acquired / Signed by India between 1990 - 2006}

\begin{tabular}{|c|c|}
\hline Types & Systems \\
\hline $\begin{array}{l}\text { Land - } \\
\text { based }\end{array}$ & $\begin{array}{l}550 \text { nos of V-46 Diesel engine (AV) for moderniza- } \\
\text { tion of T-72M1 tanks ; 3,000 nos of 9M133 Kornet/ } \\
\text { AT-14 Anti-tank missiles, including over } 250 \text { laun- } \\
\text { chers; } 12 \text { nos of AN/TPQ-37 Firefinder Arty locating } \\
\text { radar; 5,000 nos of MILAN Anti-tank missiles inclu- } \\
\text { ding MILAN-2 version; } 228 \text { nos of WZT-3 ARVs; } 310 \\
\text { + } 300 \text { nos of T-90S main battle tanks; } 6,000 \text { nos of } \\
\text { 9M113/AT-5 Spandrel Anti-tank missiles for BMP-2 } \\
\text { IFVs; } 28 \text { BM-9A52 Smerch MRL; }\end{array}$ \\
\hline $\begin{array}{l}\text { Sea - } \\
\text { based }\end{array}$ & $\begin{array}{l}220 \text { nos of Barak SAMs; } 5 \text { nos of RAN-30X Air sur- } \\
\text { veillance radar; } 20 \text { nos of Seaguard TMX Fire control } \\
\text { radar; } 72 \text { nos of A-244/S ASW torpedo; } 2 \text { Il-38/May } \\
\text { ASW/MP ac; } 3 \text { Ka-27PL/Helix-A ASW helicopter; } 5 \\
\text { Ka-31/Helix AEW helicopter; } 16 \text { MiG-29K/Fulcrum- } \\
\text { D FGA ac for use on Gorshkov aircraft carrier (option } \\
\text { for } 30 \text { more); } 4 \text { 140mm RL Naval MRL; } 3 \text { AK-100 } \\
\text { 100mm Naval gun; } 168 \text { nos of 3M-54E1 Klub/SS-N- } \\
27 \text { Anti-ship missile; } 288 \text { nos of 9M311/SA-19 Grison } \\
\text { SAM; } 2 \text { Akula-2 Nuclear submarine (lease); } 1 \text { Gorsh- } \\
\text { kov Ac-carrier; } 6 \text { Scorpene Submarines; } 40 \text { odd air } \\
\text { surveillance radar for warships; }\end{array}$ \\
\hline $\begin{array}{l}\text { Aero- } \\
\text { space }\end{array}$ & $\begin{array}{l}80 \text { nos of EL/M-2032/2022 Ac radars; } 3 \text { EL/M-2075 } \\
\text { Phalcon AEW ac radar; } 3 \text { A-50 EhI AEW\&C aircraft; } \\
200 \text { nos of Derby BVRAAMs; } 50 \text { nos of Popeye-1 } \\
\text { ASM; } 125 \text { Kopyo Ac radar; } 1,140 \text { nos of R-27E/AA- } \\
10 \text { Alamo BVRAAM; 3,900 nos of R-73/AA-11 Archer } \\
\text { SRAAM; } 750 \text { nos of R-77/AA-12 Adder BVRAAM; } 40 \\
\text { F-404 Turbofan (F-404-GE-F2J3 version); } 140+40 \\
\text { Su-30MK/Flanker FGA ac; } 250+200 \text { AL-55 Turbofan; } \\
66 \text { Hawk-100 Trainer/combat ac; } 40 \text { Jaguar Interna- } \\
\text { tional FGA ac; }\end{array}$ \\
\hline
\end{tabular}

Source: Compiled from Arms Transfers Register, periodically published by SIPRI Yearbooks from 1990 to 2006. 
It is interesting to note that India is slowly diversifying its supply sources in recent times. All major and second-tier arms suppliers have established their presence in India. Sensing the changing times, Russia, India's largest weapons supplier accounting for around 70 percent of the Indian inventory, has been striving hard to not to let India slip away from its favorite recipient list. On the other hand, the United States has been wooing India to get a slice of the huge Indian arms bazaar. The American »Iron Triangle«, consisting of the Congress, armed forces and the military industry, seems to be in full swing to build the basis of the India-US relations on military technical cooperation ${ }^{15}$. While it will be interesting to observe as to how the world's two biggest arms suppliers jostle to influence the Indian market in future, but suffice to argue that countries like Israel, France and even the UK are likely to stay put in the military business.

More allocations for capital purchases for the past few years suggest that hardware elements of India's military modernization have been given primacy. India's hardware requirements at least for the medium term future (15 - 20 years) are considered quite substantial. Thus, one will not be surprised to witness corresponding increase in capital expenditure for the foreseeable future. However, the »unspent « syndrome mostly associated with the capital purchases must be addressed by the stakeholders of the budgetary rationalization process - the Ministry of Finance, the Ministry of Defence and the Services Headquarters. Thus, the integrated long-term defence planning must be accorded top priority. The revenue expenditure is witnessing a real term decrease for the past few years, which otherwise suggests a conscious attempt toward much desirable rationalization of revenue spending. One will not be surprised if revenue expenditure is further pruned in future. Global trends in force restructuring efforts must be closely examined by India, which otherwise address issues like force manpower planning and rightsizing. India must address these important issues keeping an eye on the changing nature and direction of security situation at local as well as global levels.

\section{Trends in India's Defence Production}

Trends in India's defence production patterns especially since the 1990s show that India has been able to an extent to initiate a number of projects for indigenous development in the defence sector. This has been partly possible due to increased allocation of funds for these projects as well as for R\&D efforts. It is expected that an increase in defence $R \& D$, which is currently increasing for some years and is likely to increase further in future, will boost indigenous effort ${ }^{16}$. However, the proportion of allocations for R\&D still remains well under ten percent. Although license production has been seen as a stable

15 Forums and trade representative bodies like the India-US Business Council, Confederation of Indian Industry (CII) and Federation of Indian Chamber of Commerce and Industry (FICCI) are very active on India-US military technical cooperation issues. The last two have each created a $»$ national committee on defence u under the parent umbrella to facilitate private sector participation in Indian defence sector as well as promote foreign collaborations between the Indian and foreign companies.

16 Deba R. Mohanty, »Future of Indian Defence Industry« in N. S. Sisodia and C Uday Bhaskar (eds.) Emerging India: Security and Foreign Policy Perspecives (New Delhi: IDSA \& Promilla Co. Publishers; 2005) form of production efforts, it has not made India self-reliant in terms of upper-ends of defence production, especially in the field of design and development. With indigenous effort having its own weaknesses, especially in financial and lack of or difficulties to access foreign military technologies, the other alternative to fill the technology gap has been contemplated for some time. This is where efforts toward joint design and development and co-production efforts come in, an opportunity largely created in the global defence industrial scenario in recent times.

Several new projects, to be jointly designed and developed with foreign firms, are coming up in the Indian defence industrial sector and India is keen to tap this opportunity to the fullest possible extent ${ }^{17}$. HAL has led the way in this effort. After successful integration of several electronic components in the Su-30MKI by the Indian scientists and technicians in recent times, the Russians are keen to offer a partnership, initially in license production of the aircraft by HAL but incrementally substituted by joint production in future, which is a new experience in this kind of fourth generation aircraft project. A new simulator making it possible to train pilots for the Su-30MKI is on the cards for India ${ }^{18}$. Russia, in addition to this, has also agreed to become a partner in the ambitious fifth-generation combat aircraft project with India ${ }^{19}$. Brahmos, another example, is a joint venture between India and Russia, three versions of which are nearing readiness for serial production and exports. This cruise missile project started in 1998 and is considered to be one of the major steps by India toward international collaboration. India's recent search for Advanced Jet Trainer (AJT) has also benefited its quest for collaboration partners. The US aviation giant Lockheed Martin is keen to offer technology transfer for the indigenous project ${ }^{20}$. This is for the first time that except for Russia, more and more front line arms producing countries are showing interests, not in exports but more importantly in joint ventures and other forms of industrial participation. Indian defence industry, especially since the last couple of years, has been experiencing noticeable changes. It is gearing up to grab this opportunity which was previously quite limited. Industry watchers believe that such changes in production policies are going to benefit Indian defence industry in many ways.

India's quest for self-reliance in defence has thus far produced mixed results. Some of the lessons that India has learned in the past fifty years are worth noting here. First, a technology gap has facilitated scope for acquisition of production technology than design technology. This in turn has created a license production regime at the cost of indigenisation efforts. During the 1990s, the effort to encourage joint ventures and coproduction with foreign firms in the Indian defence industrial sector is largely seen as a step to reduce license regime and boost indigenous industrial capabilities. A more globalised defence industrial order has proved to be helpful for India in this context. Second, private participation in the defence industrial

\footnotetext{
17 »India Keen on International Collaboration: Fernandes «, The Times of India, 5 February, 2003.

18 »Sukhoi Family Will be Present in Strength«, The Hindu, 4 February, 2003.

19 »Russia Offers India Partnership in 5th Generation Combat Aircraft Project«, The Hindustan Times, 10 February, 2006.

20 »Lockheed Looking for Technology Transfer«, The Hindu, 4 February, 2007.
} 
Table -3

\section{India's Domestic Defence Production Sector: Select-Indicators}

\begin{tabular}{|l|l|l|l|l|l|l|}
\hline $\begin{array}{l}\text { Industry /Nos of } \\
\text { Units }\end{array}$ & $\begin{array}{l}\text { Number of } \\
\text { Employees } \\
\text { (app.) }\end{array}$ & $\begin{array}{l}\text { Value of } \\
\text { Prod.: } \\
\mathbf{1 9 8 0 - 8 1} \\
\text { (mn. Rs) }\end{array}$ & $\begin{array}{l}\text { Value of } \\
\text { Prod.: } \\
\mathbf{1 9 9 0 - 9 1} \\
\text { (mn. Rs) }\end{array}$ & $\begin{array}{l}\text { Value of } \\
\text { Prod: } \\
\text { 2000-01 } \\
\text { (mn. Rs) }\end{array}$ & $\begin{array}{l}\text { Major Production } \\
\text { (Indigenous and } \\
\text { Others including } \\
\text { future projections) }\end{array}$ & $\begin{array}{l}\text { Defence/Civil } \\
\text { Sales as \% } \\
\mathbf{( 1 9 9 3 - 9 4 )}\end{array}$ \\
\hline $\begin{array}{l}\text { Ordnance Facto- } \\
\text { ries/39 }\end{array}$ & $1,73,000$ & 6,710 & 26,510 & 55,360 & $\begin{array}{l}\text { Arjun, T-90, T-72, ICVs, } \\
\text { INSAS }\end{array}$ & $90 / 10$ \\
\hline $\begin{array}{l}\text { Hindustan Ae- } \\
\text { ronautics Limi- } \\
\text { ted/14 }\end{array}$ & 45,000 & 1,580 & 8,958 & 26.032 & $\begin{array}{l}\text { Cheetah, Chetak, Ma- } \\
\text { rut, MiGs, LCA, PTA, } \\
\text { ALH, etc }\end{array}$ & $94 / 06$ \\
\hline $\begin{array}{l}\text { Bharat Electro- } \\
\text { nics } \\
\text { Limited/9 }\end{array}$ & 19,400 & 808 & 7,002 & 17,875 & $\begin{array}{l}\text { Sonars, communication } \\
\text { systems, electronics }\end{array}$ & $45 / 55$ \\
\hline $\begin{array}{l}\text { Bharat Earth } \\
\text { Movers Limited } \\
\text { /4 }\end{array}$ & 15,800 & 982 & 7,793 & 13,431 & $\begin{array}{l}\text { Military vehicles, heavy } \\
\text { earth moving equip- } \\
\text { ment }\end{array}$ & $6 / 94$ \\
\hline $\begin{array}{l}\text { Mazagaon Dock- } \\
\text { yard Limited/4 }\end{array}$ & 13,700 & 869 & 3,085 & 7,115 & $\begin{array}{l}\text { Delhi class, Veer cor- } \\
\text { vettes, Khukri }\end{array}$ & $45 / 55$ \\
\hline $\begin{array}{l}\text { Garden Reach } \\
\text { Shipbuilders \& } \\
\text { Engineers Lim- } \\
\text { ited/2 }\end{array}$ & 10,300 & 392 & 1,868 & 4,910 & $\begin{array}{l}\text { Brahmaputra class Frig- } \\
\text { ates, Khukri, merchant } \\
\text { ships }\end{array}$ & $82 / 18$ \\
\hline $\begin{array}{l}\text { Goa Shipyard } \\
\text { Limited/1 }\end{array}$ & 2,200 & 688 & 810 & 1900 & $\begin{array}{l}\text { Samar OPV, Fast attack } \\
\text { Patrol crafts, Sukanya } \\
\text { OPV }\end{array}$ & $99 / 01$ \\
\hline $\begin{array}{l}\text { Bharat Dynamics } \\
\text { Limited/1 }\end{array}$ & 2,000 & 404 & 1370 & 2,186 & $\begin{array}{l}\text { Prithvi missiles, Akash, } \\
\text { Trishul SAMs, Nag } \\
\text { ATGM, INSAS LMG, etc }\end{array}$ & $99 / 01$ \\
\hline $\begin{array}{l}\text { Mishra Dhatu } \\
\text { Nigam Limited/1 }\end{array}$ & 1,500 & 160 & 456 & $\begin{array}{l}\text { Various alloys, spe- } \\
\text { cialised metal plates } \\
\text { and others }\end{array}$ & $50 / 50$ \\
\hline
\end{tabular}

Source: Annual Report, Ministry of Defence, Government of India, for relevant years.

Annual Report, Ordnance Factories and DPSUs, for relevant years.

sector has come after a long delay. Although it is too early to predict the nature and future direction of the role of private industry in defence production, it's likely contribution is considerable in future. Third, the government has emphasised measures to enhance the defence industry to cope with future challenges occurring out of reform initiatives. Fourth, the government is now encouraging the defence industry to have more independent joint-design and development and production collaborations to reduce dependence on imports. Fifth, the government is also contemplating on a viable strategy for exports of arms. The recent announcement by the Indian government to give export related incentives, including subsidies, to the industry is an example of this strategy. If current efforts at indigenized products, especially in the fields of electronics, aerospace, missiles are taken into consideration, it is assumed that by the end of the current decade, India might be able to save some quantum of foreign exchange through import substitution. On the other hand, products like Brahmos and Advanced Light Helicopters promise enough potential to be likely global products in the future ${ }^{21}$. International arms market being extremely competitive, it is too early to project or expect success. But, on the other hand, an incremental approach to enter the market is perhaps viable as India is currently gearing up to enter the regional market as a first step. It is too early to expect miracles but the industry seems upbeat about crossing the national boundary.

\section{Reforms in the Higher Defence Organizations}

India has undertaken a comprehensive review of its security interests as well as initiated major reforms in the higher defence organizations in recent times. Within the universe of reforms in higher defence organizations, a series of initiatives

21 Note 15. Also see, Deba R. Mohanty, „Changing Times? Indian's Defence Industry in the 21st Century«, BICC Monograph No. 36. Bonn International Center for Conversion, Germany, July 2004, available at <www.bicc.de>. 
has been undertaken in the fields of defence production and procurement. At the structural levels, a layered architecture has been established with suitable modifications in the previous arrangements to address issues related to defence production and procurement. Following the recommendations made by the Group of Ministers (GoM) Report ${ }^{22}$ in early 2001, a Defence Acquisition Council (DAC) has been established with the Defence Minister as head. DAC is entrusted with the responsibility of making policy choices related to production and procurement. Policy decisions related to production and procurement encompass three categories of choices - outright purchase of complete systems categorized as »buy«, judicious mixture of purchase and then make the same system at home through joint ventures or collaborative efforts by both Indian and foreign manufacturers categorized as »buy and make« and complete indigenous manufacture of systems categorized as "make « ${ }^{23}$. The DAC will make policy decisions on all these three categories. Once the policy choices are made, three almost parallel institutions - Defence Production Board (DPB), Defence Procurement Board (DPB) and Defence Research and Development Board (DRDB) will be responsible for implementation of such decisions. The Defence Procurement Board under the Defence Secretary will have the primary role of capital procurements and co-ordination. The Defence Production Board is headed by the Secretary Defence Production and Supplies and will oversee all activities related to indigenous manufacture, progress in "make« projects and will provide support to DAC. The Defence R\&D Board will be headed by the Secretary Defence R\&D and will oversee progress, monitor and report on all R\&D proposals in consultation with the user services and production board. Apart from these, the newly created office of the Director General Defence Acquisitions, headed by a Special Secretary level civil servant, will provide inputs to both the DPB and the DAC. Requirements of the respective arms of the Services will be channeled to the headquarters of Integrated Defence Staff (HQ IDS), who will in turn prepare a comprehensive 15 years Long-Term Integrated Perspective Plan (LTIPP) and five years Services Capital Acquisition Plan (SCAP) for acquisition purposes. The LTIPP and SCAP will be considered by DAC at the highest level. In brief, a new set of organizational structure, by suitably modifying the earlier structure with additions wherever necessary, has been instituted recently to cater to the changing procurement requirements. Following the GoM's Report, the Indian government came out with a major policy decision in early 2002 to open up the defence industrial sector for private sector participation. Through an official notification brought out by the Department of Industrial Promotion and Policy, under the

22 This is by far the most comprehensive report on national security management by a very high level committee constituted by the Government of India. Soon after the Kargil conflict, the Government constituted a Committee under the Chairmanship of Mr K Subrahmanyam to look into the cause of the conflict as well as recommend effective steps for national security management. The GoM Committee was subsequently constituted in early 2000 , which submitted its report in February 2001. For details, see, »Reforming the National Security System: Recommendations of the Group of Ministers«, Report of the GoM on National Security, National Security Council Secretariat, New Delhi, February 2001

23 Ministry of Defence, Government of India, came out with a new defence procurement policy, known as DPP - 2006, in late August 2006. Details of DPP - 2006, published in two parts - DPP: Capital Procurement and DPP: Revenue Procurement, can be found in <www.mod.nic.in>
Ministry of Commerce, the Indian government announced 100 percent participation by Indian private sector in the defence industrial units and allowed for 26 percent foreign direct investment (FDI). Between 2002 and early 2007, the government has already issued more than 39 licenses to the Indian private firms ${ }^{24}$ for manufacture of items like infantry combat vehicles, multiple barrel rocket launchers and a few low-end defence products. Companies like the Tatas, Mahindras and Mahindras, Kirloskar, Larsen and Toubro are already in defence business in India.

\section{The Indian Arms Dynamic: Future Directions}

Trends in global military efforts have unleashed a set of challenges and opportunities for India. While challenges range from adjusting to competitive nature of arms trade especially in the context of India's current and future weapons procurement, opportunities have come in terms of multiple choices for partnership in production. Products at competitive prices along with a bigger package, which may include technology transfers and offsets, are the most preferred option for India. India's diplomatic efforts could play a proactive role in the international arms market. Signs of this new venture are already showing, where India is seen wooing several countries to advance its core interests. A twin strategy - fostering reliable long-term partnerships with countries like the US and bargaining for technological and associated benefits in arms transactions - could be in place for the future. India's diplomacy has another core area of responsibility in the field of arms exports. Although at a nascent stage, India's export potential is likely to grow in the future, this, in turn, will test its diplomatic skills to sell its products. This way, India's aspirations to become at least a viable second-tier defence producer could be realized, although much homework needs to be done in this regard.

Reforms in Indian higher defence management with emphases on enhancing national security seem a step in the right direction keeping global trends in mind. Self-reliance in defence technologies ${ }^{25}$, including critical technologies, must be accorded top priority, whereby a twin strategy is seemingly underway - developing systems through indigenous routes as well as gaining knowledge from technology diffusion and international collaborative efforts. Role of DRDO and other scientific institutions will be extremely critical in coming years. Major defence industrial units in India must carry on structural and organisational level reforms, in keeping with changing developments taking place at international levels. The Indian government must find ways to give them enough independence as well as encourage them to go flat out in the global market. Aerospace, electronics and missiles being the core future market, conglomerates like Hindustan Aeronau-

24 A detailed list of license production contracts awarded to the Indian private companies can be found in note 22 .

25 For a comprehensive analysis of defence technologies for future needs for India, see, Amitav Mallick, »Self-Reliance in Defence Technologies « in Satish Kumar (ed.) India's National Security: Annual Review 2003 (New Delhi: India Research Press; 2003). Also see, V. Siddhartha, »Technology in the Future Needs of Our Armed Forces« in Satish Kumar (ed.), India's National Security: Annual Review 2001 (New Delhi: Vikas Publishers; 2001). 
tics Limited, Bharat Electronics Limited and Bharat Dynamics Limited, which have shown commendable performance in recent times, must be unleashed to tap the global opportunities. India's entry into the future global market should be through "pockets of excellence « approach, which should be the future defence industrial strategy for India. Role of private participation in military efforts must be further expanded to include involvement in complex, high-tech futuristic systems development.

India's arms purchases have gone up substantially in recent times. A closer look at India's arms purchases would show that while much of the acquisitions have been to replenish the outdated and aging systems in its inventory, some of the systems in the pipeline like the joint fifth-generation combat aircraft project or cruise missile project are undertaken to supplement India's future needs. A major part of the acquisition is also due to the fact that the Indian $R \& D$ and production establishments have failed to deliver earlier promised systems like the LCA or specific indigenous missiles. Delays in indigenous projects are likely to retard the self-reliance process and in turn may force the government to opt for outright purchase of several items. An effort to diversify sources of supply has also been evident in the past few years, which otherwise suggest that while traditional suppliers like Russia are taking note of India's changing priorities, new suppliers are trying to get a foothold in the Indian market, most notably the United States and Israel.

India's track record in military efforts has been noticed in recent times, primarily because of its arms acquisition spree and reforms initiated in the defence industrial sector as well as higher military organisations. India's procurement strategy, which includes both current as well as future generation weapons systems, does not seem to be tied to an arms race phenomenon within the Indian sub-continent with Pakistan or within the greater Asia with China now, although a few systems like medium range missiles or medium range combat aircraft or third generation warships are kept for regional security purposes. India's quest for long-range systems along with equipment for its modernizing Special Forces are some of the indications of its intention to go beyond the traditional continental boundaries for defence purposes.
Post nuclear tests in the Indian sub-continent and the Kargil conflict with Pakistan in the late 1990s, India has strived to initiate major reforms in the security sector. The nuclear issue and regional security issues have dominated the security discourse since then. Nonproliferation as well as nontraditional security issues have since cropped up in more vocal terms even though such issues have been in security discourse for preceding decades. Pakistan has stepped up its military modernization programme, which among others, denote a strive toward quantitative parity with India. Its arms acquisitions as well as domestic missile and other military industrial programmes have strived to ensure its national interest protection. China, on its part, has stepped up its military modernization programme, a subject that needs a series of papers altogether. Suffice to say that China's military modernization efforts are multi-directional: while much of its futuristic programmes are geared toward the United States and other powers like Russia and Japan, some of its military programmes have been set to take car of India as well. In sum, while cognizable traditional and nontraditional threats emanate from both Pakistan and China and even when India's relations with both its traditional rivals are improving in recent times, India cannot afford to divert its security attention and priorities for alternative purposes. Besides, India's new found confidence seems to transcend regional security confines while taking effective care of its immediate neighborhood.

India's military modernization efforts seem to have entered a new phase of transformations that seem to promise a new actor in international relations. India's consistent desire to play an independent role in international affairs during the Cold War period was largely unnoticeable as the international security scenario was primarily dominated by superpower rivalries. With the end of the Cold War and subsequent fluidity in international security situation and coupled with challenges of the immediate neighborhood in and around the Indian subcontinent, India's role seems to have been shaped more by a desire to play a strategic stabilizer at the world stage than a mere traditional regional player. As security driven modernization efforts often lead to a perpetual web of insecurity syndrome, India's military modernization efforts must take note of strategic implications of its military prowess in the region and beyond and it must craft its security policies in tune with changing times. 